ZOOLOGIA 31 (6): 621-633, December, 2014

http://dx.doi.org/10.1590/S1984-46702014000600008

\title{
Fusceulima and Halielloides (Gastropoda: Eulimidae) in the southwestern Atlantic, with descriptions of two new species of Fusceulima
}

\author{
Leonardo Santos de Souza \& Alexandre Dias Pimenta
}

Departamento de Invertebrados, Museu Nacional, Universidade Federal do Rio de Janeiro. Quinta da Boa Vista, São Cristóvão, 20940-040 Rio de Janeiro, RJ, Brazil.E-mail: leosouza2301@gmail.com; alexpim@mn.ufrj.br

\begin{abstract}
Fusceulima Laseron, 1955 and Halielloides Bouchet \& Warén, 1986 are reported from the southwestern Atlantic for the first time. Halielloides ingolfiana Bouchet \& Warén, 1986 is considered a valid name, and the taxon is distinct from its previous senior synonym Eulima verrilliana Bush, 1909 in shell shape and absence of an umbilicus. Fusceulima saturata sp. nov. is characterized by a conical shell, domed at the apex, a short ovoid aperture, and a distinct dark-brown spiral band near the suture. Fusceulima toffee sp. nov. also has a conical shell and a dome-shaped apex, but has a taller high aperture and the entire shell is dark brown. Halielloides cf. ingolfiana, Fusceulima cf. boscheineni, and Fusceulima cf. minuta, are here recorded from the continental shelf off southeastern Brazil. The nominal species of these taxa were originally described from the northeastern Atlantic. Their status remains dubious because of lack of information on their biology, anatomy and molecular data. Regarding shell morphology, we cannot distinguish the Brazilian specimens from species in the northeastern Atlantic with the material available. A series of short grooves close to the suture of the protoconch in all species of Fusceulima, including the type species Fusceulima jacksonensis Laseron, 1955, is a possible diagnostic character for this genus.
\end{abstract}

KEY WORDS. Eulimids; Eulimoidea; Halielloides ingolfiana; taxonomy; West Atlantic.

Eulimidae Philippi, 1853 consists of a large and diverse group of marine microgastropods, with approximately 1000 valid species (BOUCHET 2014), most of which are parasites of echinoderms (WARÉN 1984). The Eulimidae is one of the five most species-rich families of marine gastropods in the IndoPacific (Bouchet et. al. 2002, Albano et al. 2011). This diversity is not related exclusively to the number of extant species, but also to the wide range of parasitic strategies (TAKANO \& KanO 2014). Despite these large numbers and differences in life habits, the morphology of the shell differs mainly in the general shape: some genera are very distinct in the latter and are easily recognizable, whereas others have very similar morphology and their limits are difficult to identify. The scarcity of morphological characters on the shell (e.g., axial ribs and spiral cords) poses a challenge for taxonomists (DGeBuAdze et al. 2012).

In the western Atlantic, eulimids are represented by 147 species and 37 genera (Rosenberg 2009). Of these, only 28 species, distributed in ten genera, are known from Brazil: Annulobalcis Habe, 1965 (two species), Batheulima F. Nordsieck, 1968 (two), Costaclis Bartsch, 1847 (one), Eulima Risso 1826 (four), Eulimostraca Bartsch, 1917 (two), Melanella Bowdich, 1822 (nine), Niso Risso, 1826 (two), Oceanida Folin, 1870 (two), Pisolamia Bouchet \& Lutzen, 1976 (one), Scalenostoma (two) and Thaleia Warén, 1979 (one) (Folin 1867, Watson 1883, LeAL 1991, Barros et al. 2001, Simone 2002, Lima et al. 2005, Simone \& Birman 2006, Rios 2009, QueIroz et al. 2013), in addition to record of Halieloides (ABSALÃo 2010). The most recent eulimids reported from the western Atlantic were described by Espinosa et al. (2007), and since this contribution this family has received little attention in this region.

Recent oceanographic campaigns off southeastern Brazil and collection-based studies have revealed large numbers of unknown eulimids. A taxonomic review of the Eulimidae (in progress) using the material from the Campos Basin, southeastern Brazil, has led to the discovery of several species, including species of Fusceulima Laseron, 1955 and Halielloides Bouchet \& Warén, 1986, which are the topic of this paper.

Members of Fusceulima occur in all oceans (Thiele 1925, LASERON 1955, Bouchet \& WaréN 1986), but in the Atlantic, records of this genus are limited to the north - northeastern region. Fusceulima currently comprises 18 species (Bouchet \& Gofas 2014). The distribution of Halielloides is limited to the North Atlantic (Bouchet \& WARÉN 1986), with only two valid species. Halielloides nitida (Verrill, 1884) is the only member of the genus known from the western Atlantic, on the USA coast, based on a synonymy (WARén 1991). No records from Fusceulima and Halielloides have been reported from the southwestern Atlantic.

In this study, we report for the first time the presence of species of Fusceulima and Halielloides in the southwestern Atlantic, based on empty shells collected in the Campos Basin, southeastern Brazil $\left(20.5-24^{\circ} \mathrm{S}, 40-41^{\circ} \mathrm{W}\right)$.

2014 Sociedade Brasileira de Zoologia | www.sbzoologia.org.br | www.scielo.br/zool All content of the journal, except where identified, is licensed under a Creative Commons attribution-type BY-NC. 


\section{MATERIAL AND METHODS}

The taxonomic identifications were based on conchological comparisons with type material and/or original descriptions and illustrations. Almost all species treated here were illustrated using scanning electron microscope (SEM) images.

The terminology used for conchological features follows BOUCHET \& WARÉN (1986). The method used to count the number of whorls of the protoconch is in accordance with LeAL (1991).

Most of the material examined is from two projects: (HAB) Projeto Habitats - "Heterogeneidade Ambiental da Bacia de Campos" (Habitats Project - Campos Basin Environmental Heterogeneity), carried out by CENPES/PETROBRAS; Collector: Research Vessel "Miss Emma McCall"; (REVIZEE) "Programa de Avaliação do Potencial Sustentável de Recursos Vivos da Zona Econômica Exclusiva" (Program of Evaluation of the Sustainable Potential of Living Resources in the Economic Exclusive Zone), of the Ministério do Meio Ambiente, Brazilian Government; collectors: REVIZEE Central campaign 1: Oceanographic Ship "Antares". The remaining material was collected by other short campaigns in Campos Basin (Southeast Brazil) that are not related to a major project.

In the material examined, the number inside the brackets indicates number of shells in each lot. In addition to the material examined listed, the holotype of Eulima verriliana Bush, 1909 (USNM 38182) and syntypes of Fusceulima jacksonensis Laseron, 1955 (AMS C.103028 [7 shells]) were also studied by us.

Abbreviations used throughout the text are as follows: AMS: Australian Museum, Sidney, Australia; IBUFRJ: Instituto de Biologia, Universidade Federal do Rio de Janeiro, Rio de Janeiro, Brazil; MNHN: Muséum national d'histoire naturelle, Paris, France; MNRJ: Museu Nacional/Universidade Federal do Rio de Janeiro, Rio de Janeiro, Brazil; MORG: Museu Oceanográfico Eliézer de Carvalho Rios, Rio Grande, Brazil; MZSP: Museu de Zoologia da Universidade de São Paulo, São Paulo, Brazil; NHMUK: Natural History Museum, London, United Kingdom; SMNH: Naturhistoriska riksmuseet, Stockholm, Sweden; USNM: Smithsonian National Museum of Natural History, Washington D.C., United States of America; ZMUC: Zoologisch Museum University of Copenhagen, Copenhagen, Denmark.

\section{TAXONOMY}

\section{Halielloides Bouchet \& Warén, 1986}

Halielloides Bouchet \& Warén, 1986: 342. Type species by original designation: Halielloides ingolfiana Bouchet \& Warén, 1986: 342 , Off Iceland, Ingolf sta. $90,64^{\circ} 45^{\prime} \mathrm{N}, 29^{\circ} 06^{\prime} \mathrm{W}$, 1070 m depth (Fig. 1).

Diagnosis. Short, cylindrical shell, convex whorls, a strongly arched but weakly opisthocline outer lip. An ovate aperture and reflected inner lip with a distinct umbilical fissure (based on BOUCHET \& WARÉN 1986).

\section{Halielloides cf. ingolfiana Bouchet \& Warén, 1986}

Figs 2-10

Characterization. Vitreous shell, cylindrical with a broad, obtuse apex, reaching $2.8 \mathrm{~mm}$ in length. Larval shell about 1.7 whorls, diameter about $400 \mu \mathrm{m}$; smooth. Teleoconch with up to six whorls and a rounded outline, strongly convex; suture deep and distinct, sinuous; subsutural zone distinct, narrow, occupying about 0.2 height of each whorl; surface sculptured by indistinct growth lines; incremental scars strong, well demarcated, appearing irregularly in number (4-6) and intervals (0.4-1.2 whorls). Last whorl comprising 0.4 total shell length; base elongated with rounded outline. Aperture high, elongated, ovoid, slightly pointed posteriorly with a rounded anterior margin; outer lip thin, with a sinuous profile, deeply sinuate below suture, evenly curved downwards, projecting most in the lower half; inner lip slightly projected into parietal region; columella straight.Small umbilical fissure.

Dimensions. Largest specimen with approximately 6 whorls; length $2.8 \mathrm{~mm}$; width $1.0 \mathrm{~mm}$; aperture height $0.9 \mathrm{~mm}$; aperture width $0.6 \mathrm{~mm}$.

Type Material of Halielloides ingolfiana. Holotype ZMUCGAS 1105; paratypes ZMUC-GAS 1106 [5 shells], type locality.

Type locality of Halielloides ingolfiana. Off Iceland, INGOLF sta $90\left(64^{\circ} 45^{\prime} \mathrm{N}, 29^{\circ} 06^{\prime} \mathrm{W}, 1070 \mathrm{~m}\right)$.

Material examined: Holotype and paratypes of Halielloides ingolfiana. Shells of Halielloides cf. ingolfiana from southeast Brazil: Espírito Santo state, Campos Basin: REVIZEE Central sta VV

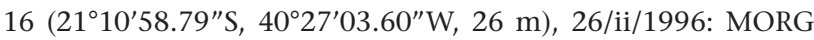
40160 [5 shells]; Rio de Janeiro state, Campos Basin: HAB 13 sta H4 (2142'49.55"S, 40¹0'22.39”W, 98 m), 09/iii/2009: MNRJ

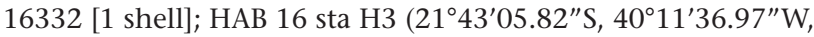
73 m), 08/vii/2009: MNRJ 17711 [4 shells], IBUFRJ 19685 [1 shell];

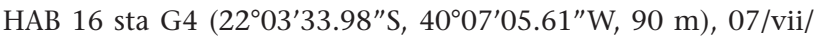
2009: MNRJ 17716 [1 shell]; HAB 16 sta D5 (22 $31^{\prime} 02.68^{\prime \prime}$, 40³1'39.03"W, $137 \mathrm{~m}), 03 / \mathrm{vii} / 2009:$ MNRJ 17717 [1 shell]; (22 $42^{\prime} 48.69^{\prime \prime}$ S, $\left.40^{\circ} 51^{\prime} 19.62^{\prime \prime} \mathrm{W}, 110-120 \mathrm{~m}\right), 19 / \mathrm{ix} / 2003$ : MNRJ 31885 [1 shell], MNRJ 31253 [1 shell]; (2242'48.69"S, 4051'19.62"W, 110-120 m), iii/2007: MNRJ 31838 [1 shell]; REVIZEE Central sta D3 (22 $\left.52^{\prime} 58^{\prime \prime} \mathrm{S}, 41^{\circ} 09^{\prime} 14^{\prime \prime} \mathrm{W}, 80 \mathrm{~m}\right), 23 / \mathrm{ii} /$ 1996: IBURFJ 11454 [ 1 shell]; (230.'14.30"S, 4059'30.69"W, $100 \mathrm{~m}), x i i / 2004:$ MNRJ 31907 [1 shell], MORG 50137 [1 shell]; (2305'22.73"S, 4058'55.52"W, 100 m), ix/2004: MNRJ 31906

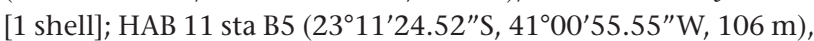
21/ii/2009: MNRJ 17669 [1 shell].

Geographic distribution: Halielloides ingolfiana: Norway; Iceland; Greenland; Portugal. Depth range 150-2000 m (Bouchet \& WarÉn 1986, WARÉN 1991). Halielloides cf. ingolfiana: Brazil: states of Espírito Santo and Rio de Janeiro, Campos Basin, from 26 to $137 \mathrm{~m}$ depth (this study).

Remarks. The holotype of Halielloides ingolfiana was illustrated by Bouchet \& WaréN (1986) in a drawing, and is here illustrated by a photograph for the first time (Fig. 1). Bouchet \& WARÉN (1986) considered Halielloides nitida (= Eulimella nitida 


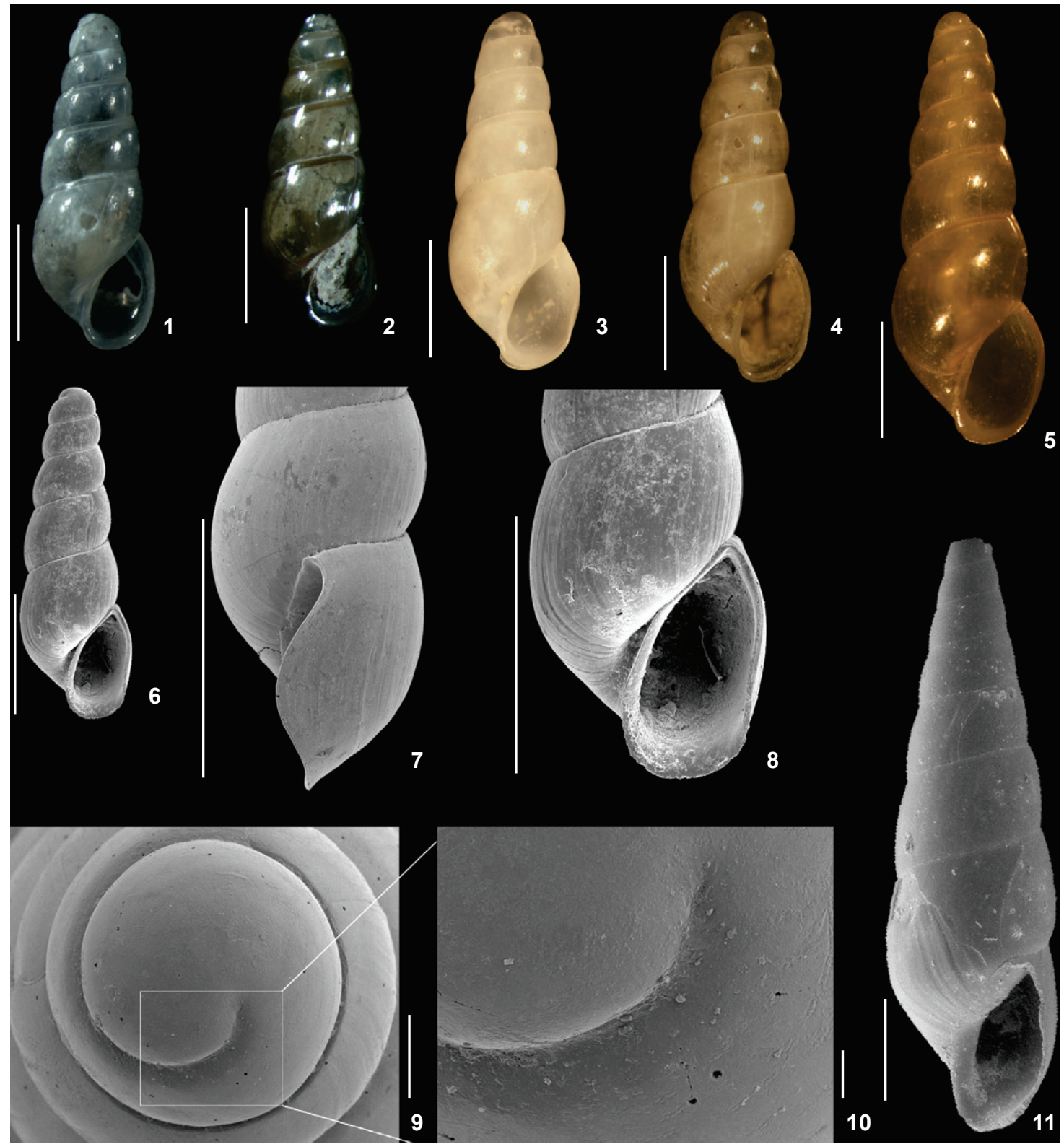

Figures 1-11. (1) Halielloides ingolfiana, holotype, whole shell, ZMUC-GAS 1105. (2-10) Halielloides cf. ingolfiana: (2) MNRJ 17711; (3) MNRJ 17717; (4) IBUFRJ 19681; (5) MORG 50137; (6, 8) MNRJ 31838; (7, 9-10) MORG 40160. (2-6) whole shells; (7-8) last whorl; (9) protoconch in apical view; (10) detail of suture at outset of protoconch; (11) Eulima verrilliana, holotype, whole shell, USNM 38182. Scale bars: $1-8,11=1.0 \mathrm{~mm}, 9=100 \mu \mathrm{m}, 10=20 \mu \mathrm{m}$.

Verrill, 1884 = Eulima verrilliana Bush, 1909) as a very similar species that differs in size (larger) and in having a more oblique aperture and weaker incremental scars. BOUCHET \& WARÉN (1986) also mentioned the possibility of these two species becoming synonyms, and later, WARÉN (1991), based on additional material from other localities in the northeastern Atlantic, concluded that there is more variation in specimens of $H$. ingolfiana than in the material observed by BOUCHET \& WARÉN (1986), which led him to confirm $H$. ingolfiana as a synonym of $H$. nitida.

However, examination of the holotype of Eulima verrilliana (Fig. 11) revealed a different shell, with a more-conical shape and less-convex whorl profile. In addition, $E$. verrilliana lacks the umbilical fissure, as stated by VeRRILL (1884) in the original description. The umbilical fissure is a diagnos- 
tic character of Halielloides (Bouchet \& Warén 1986), as are the cylindrical shell and convex whorls. The protoconch of $E$. verrilliana is broken and does not permit a comparison. Thus, we consider $H$. ingolfiana as a valid name, and also consider that the generic assignment of Eulima verriliana requires further investigation.

Shells from southeastern Brazil (Figs 2-10) are very similar in shape and sculpturing (growth lines) to the holotype of $H$. ingolfiana, with strongly convex whorls and an easily recognizable umbilical fissure (Fig. 8). However, the mean diameter of the protoconch is smaller (narrower) in shells from Brazil, approximately $400 \mu \mathrm{m}$, and the protoconch reaches about 1.7 whorls. Shells of $H$. ingolfiana have a protoconch with approximately 1.2 whorls and a diameter of $530 \mu \mathrm{m}$. Concerning the color, the Brazilian specimens are also vitreous or whitish, but some have a slightly yellow tint (Fig. 5).

Considering $H$. ingolfiana as a valid name, there are no records of Halielloides from the western Atlantic. Halielloides cf. ingolfiana is quite distinct from any other named western Atlantic eulimid; the extremely close similarity in the shell morphology of Brazilian specimens with the shells of $H$. ingolfiana from the northeastern Atlantic prevents us from discriminating them. However, since we have no data to support the amphi-Atlantic distributions of this species, and given the limited bathymetric distribution (restricted to the continental shelf) of the material from southeastern Brazil, we hesitate to identify the material examined here as $H$. ingolfiana. A more reliable identification will depend on examination of soft parts and material from the continental slope off Brazil.

\section{Fusceulima Laseron, 1955}

Fusceulima Laseron, 1955: 95. Type species by original designation. Fusceulima jacksonensis Laseron, 1955, North Harbour, Port Jackson, New South Wales, between tidemarks (Figs 12-19).

Diagnosis. Small shell (1.5-4.0 mm high), broad and domed apex; few whorled (4-6 whorls), whorls almost flat, last whorl about half total length; aperture short, outer lip curved; brownish to yellowish or colorless. Based on LASERON (1955) and BOUChet \& WARÉN (1986).

\section{Fusceulima cf. boscheineni Engl, 1998} Figs 22-28

Characterization. Shell conical with a wide spire angle, and a broad, obtuse apex, reaching $1.5 \mathrm{~mm}$ in length. Larval shell approximately 1.5 whorls, diameter about $240 \mu \mathrm{m}$; smooth, with short, fine striations below suture, from the nucleus to the strongly recurved terminal scar at the transition to teleoconch. Teleoconch with up to three whorls of slightly sinuous outline, with a very slight convexity on the lower region; suture shallow, rectilinear; subsutural zone distinct, occupying about 0.2 height of each whorl; surface glossy and smooth; incremental scars weak, approximately 4 , with

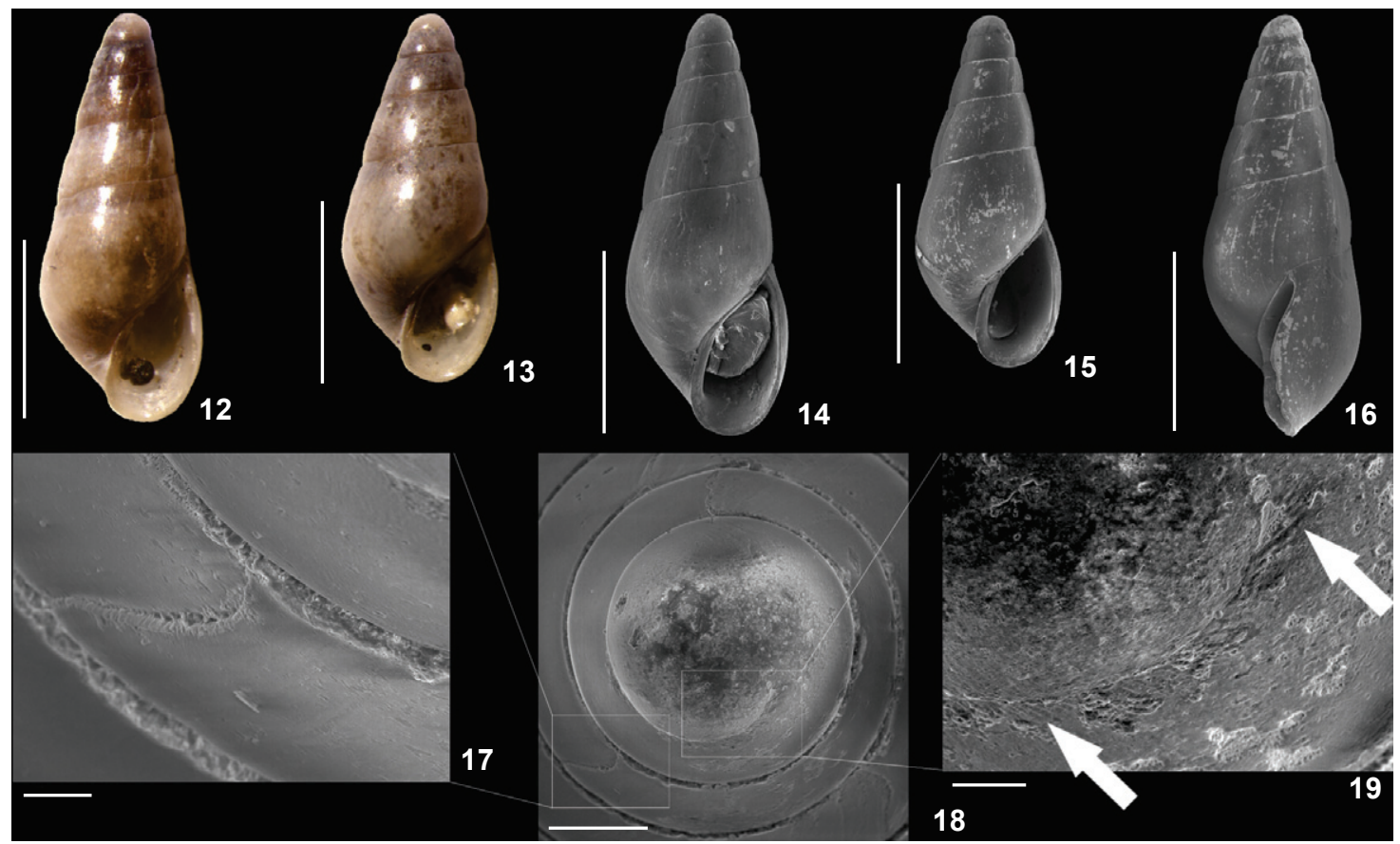

Figures 12-19. Fusceulima jacksonensis, syntypes AMS C.103028: (12-16) whole shells; (17) detail of the terminal scar; (18) protoconch in apical view; (19) detail of suture at outset of protoconch. Scale bars: 12-16=1.0 mm, 17, $19=20 \mu \mathrm{m}, 18=100 \mu \mathrm{m}$. 


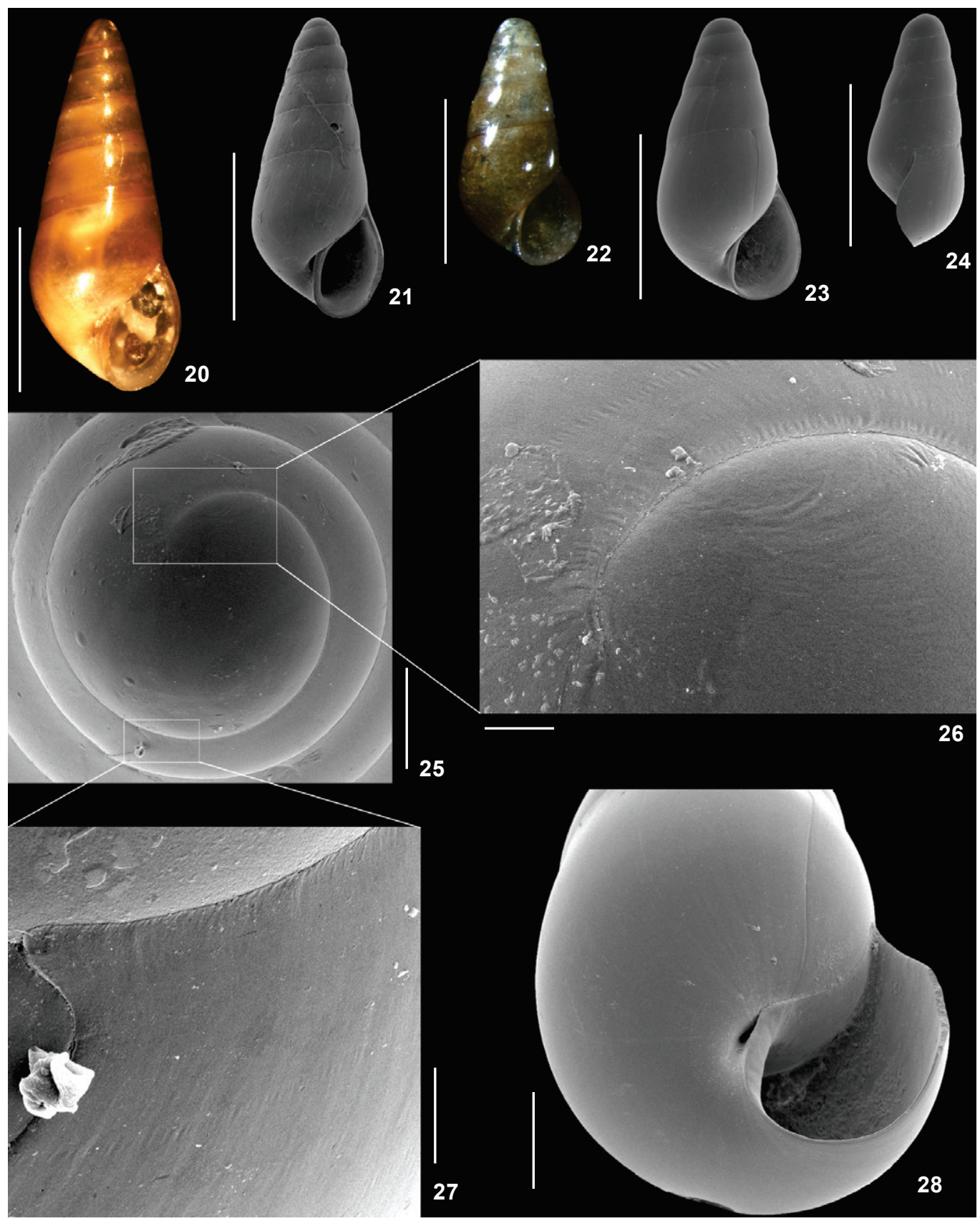

Figures 20-28. (20-21) Fusceulima boscheineni, topotypes, W. Engl personal collection: whole shells. (22-28) Fusceulima cf. boscheineni; $(22,24)$ MNRJ 17403; (23) MNRJ 31903; (25-27) MNRJ 31903; (28) MNRJ 31903. (22-24) whole shells; (25) protoconch in apical view; (26) detail of suture at outset of protoconch; (27) detail of grooves near the terminal scar; (28) detail of the umbilical fissure. Scale bars: $20-24=1.0 \mathrm{~mm}, 25=100 \mu \mathrm{m}, 26-27=20 \mu \mathrm{m}, 28=200 \mu \mathrm{m}$.

intervals near 0.7-1.0 whorls. Last whorl about 0.6 total shell length; base elongated with rounded outline. Aperture ovoid, pointed posteriorly, laterally expanded, with a rounded anterior margin; outer lip thin, with sinuous profile, deeply sinu- ate below suture, evenly curved downward, with the most projecting part in the lower half; inner lip slightly projected into parietal region; columella straight. Small, chink-like umbilicus. Fresh shells with brownish/gold spots. 
Dimensions. Largest specimen about 5 whorls; length $1.5 \mathrm{~mm}$; width $0.7 \mathrm{~mm}$; height of aperture $0.6 \mathrm{~mm}$; width of aperture $0.3 \mathrm{~mm}$.

Type material of Fusceulima boscheineni. Holotype SMNH 4898; several Paratypes listed by Engl (1998).

Type locality of Fusceulima boscheineni. Puerto del Carmen, Lanzarote, Canary Islands, 45-50 m.

Material examined. Topotypes of Fusceulima boscheineni: Winfried Engl personal collection [3 shells].

Shells of Fusceulima cf. boscheineni from southeast Brazil: Rio de Janeiro state, Campos Basin: (22 42'48.69"S, 4051'19.62”W, 110-120 m), 19/x/2003: MNRJ 31884 [3 shells], MNRJ 32887 [2 shells]; HAB 16 sta C4 (2251'57.63"S, 4057'35.17"W, 92 m) 03/ vii/2009: MNRJ 17403 [3 shells]; (2305'22.73"S, 4058'55.52"W, 100 m), ix/2004: MNRJ 31903 [1 shell], IBUFRJ 19684 [1 shell]; Campos Basin, P.M.S. Costa leg. 2003: MORG 48594 [1 shell].

Geographic distribution. Fusceulima boscheineni: Canary Islands, Northeast Atlantic (ENGL 1998). Fusceulima cf. boscheineni: Brazil: Campos Basin, Rio da Janeiro state, from 52 to $92 \mathrm{~m}$ depth (this study).

Remarks. Although the holotype of $F$. boscheineni is a larger shell, reaching six whorls, with a somewhat elongate shape, while all shells from Brazil are shorter with the maximum of five whorls, some paratypes of $F$. boscheineni have shorter shells, similar to the shells from Brazil. Fusceulima projectilabrum Bouchet \& Warén, 1986 from the northeastern Atlantic, including also records from Greenland (WARÉN 1989), has a similar laterally expanded aperture and an umbilical chink, but differs in the almost cylindrical shape and the colorless shell.

Since we have no data to evaluate the possibility of a wide range of distribution in the Atlantic Ocean for species of Eulimidae, we refrain from describing a new species. Fusceulima boscheineni is limited to the continental shelf of the Canary Islands while Fusceulima cf. boscheineni is restricted to the continental shelf of the Campos Basin.

\section{Fusceulima cf. minuta (Jeffreys, 1884)}

Figs 31-36

Characterization. Shell conical to subcylindrical, with obtuse apex, reaching $1.8 \mathrm{~mm}$ in length. Larval shell with 1.8 whorls, diameter about $330 \mu \mathrm{m}$; smooth, with short, fine striations below suture, from the nucleus to the strongly recurved terminal scar at the transition to teleoconch. Teleoconch with up to three whorls with sinuous outline, and a convexity on the lower region; suture deep, rectilinear; subsutural zone distinct, occupying about 0.35 height of each whorl; surface glossy and smooth; incremental scars strongly demarcated, about five in irregular intervals of 0.3-1.1 whorls. Last whorl about 0.5 total shell length; base elongated with slightly rounded outline. Aperture ovoid, pointed posteriorly with a rounded anterior margin; outer lip thin, of sinuous profile, deeply sinuate below suture, evenly curved downward, with the most projecting part at the middle; inner lip slightly projected into pari- etal region; columella straight. Imperforate. Shell vitreous, occasionally with brownish spots.

Dimensions. Largest specimen about 5 whorls; length $1.8 \mathrm{~mm}$; width $0.6 \mathrm{~mm}$; height of aperture $0.6 \mathrm{~mm}$; width of aperture $0.3 \mathrm{~mm}$.

Type material of Fusceulima minuta. Lectotype NHMUK 1885.11.5.2064; Paralectotypes NHMUK 1885.11.5.2064, NHMUK 19790227, USNM 133157. All from type locality. Not examined.

Type locality of Fusceulima minuta. Off Morocco, Porcupine 1870 , sta $26-29$, between $36^{\circ} 44^{\prime} \mathrm{N} 9^{\circ} 08^{\prime} \mathrm{W}$ and $36^{\circ} 20^{\prime} \mathrm{N}$ $06^{\circ} 47^{\prime} \mathrm{W}, 413-662 \mathrm{~m}$.

Material examined. Shells of Fusceulima cf. minuta from southeast BrazIL, Rio de Janeiro: Campos Basin: HAB 16 sta H3 (214'05.82"S, 40¹1'36.97"W, 73 m), 08/vii/2009: MNRJ 17438 [1 shell]; HAB 17 sta D2 (22 $\left.{ }^{\circ} 12^{\prime} 48.69^{\prime \prime} \mathrm{S}, 40^{\circ} 51^{\prime} 19.62^{\prime \prime} \mathrm{W}, 52 \mathrm{~m}\right)$, 17/vii/2009: MNRJ 17402 [1 shell]; HAB 16 sta D3 (22 ${ }^{\circ} 19^{\prime} 27.44^{\prime \prime}$, $\left.40^{\circ} 37^{\prime} 25.36^{\prime \prime} \mathrm{W}, 73 \mathrm{~m}\right), 04 / \mathrm{vii} / 2009$ : MNRJ 17437 [4 shells]; HAB 16 sta C3 (22 $46^{\prime} 49.81^{\prime \prime}$ S, $\left.41^{\circ} 03^{\prime} 39.16^{\prime \prime} \mathrm{W}, 78 \mathrm{~m}\right), 02 / \mathrm{vii} / 2009$ : MNRJ 17719 [1 shell], IBUFRJ 19683 [1 shell]; HAB 16 sta C4 (22 51'57.49"S 4057'34.82"W, 90 m), 03/vii/2009: MNRJ 17651 [2 shells].

Geographic distribution. Fusceulima minuta: Iberian Peninsula and the Mediterranean (Bouchet \& Warén 1986, PenÃs et al. 2006); Morocco (Jefrefeys 1884). Depth range: empty shells from 15-662 m depth. Fusceulima cf. minuta: Brazil: Campos Basin, Rio da Janeiro state, from 52 to $92 \mathrm{~m}$ depth (this study).

Remarks. The lectotype of F. minuta (Fig. 29) is slightly more conical, but the paralectotypes (Fig. 30) have a more cylindrical shell shape, similar to the shells from Brazil. In addition, the irregular light-brown spots of the paralectotypes are also found on shells from Brazil. The material available to us was composed exclusively of empty shells, and for this reason we cannot distinguish the specimens from Brazil from the eastern Atlantic shells of F. minuta. Fusceulima cf. minuta is limited to the continental shelf of the Campos Basin, and we have no records of it in greater depths such as in the northeastern Atlantic, where $F$. minuta reaches $662 \mathrm{~m}$. However, the uncertainty about the possibility of amphi-Atlantism and the limited bathymetric distribution of the material examined here lead us to refrain from identifying Fusceulima minuta in Brazil. BOUCHET \& WARÉN (1986) discriminated Fusceulima minuta (Figs 29-30) from two other species of Fusceulima from the northeastern Atlantic (F. thalassae Bouchet \& Warén, 1986 and $F$. lineata (Monterosato, 1869); F. minuta is also different from $F$. projectilabrum in the expanded outer lip and the presence of an umbilical chink in the latter species. Fusceulima ingolfiana Bouchet \& Warén, 1986 differs in the strong convexity of the whorls. Fusceulima sordida (Watson, 1897) is quite similar to the paralectotypes of $F$. minuta in its cylindrical shape, but the whorls are almost perfectly flat and according to the description of Watson (1897), F. sordida possesses a minute chink behind the inner lip that is not present in F. minuta. 


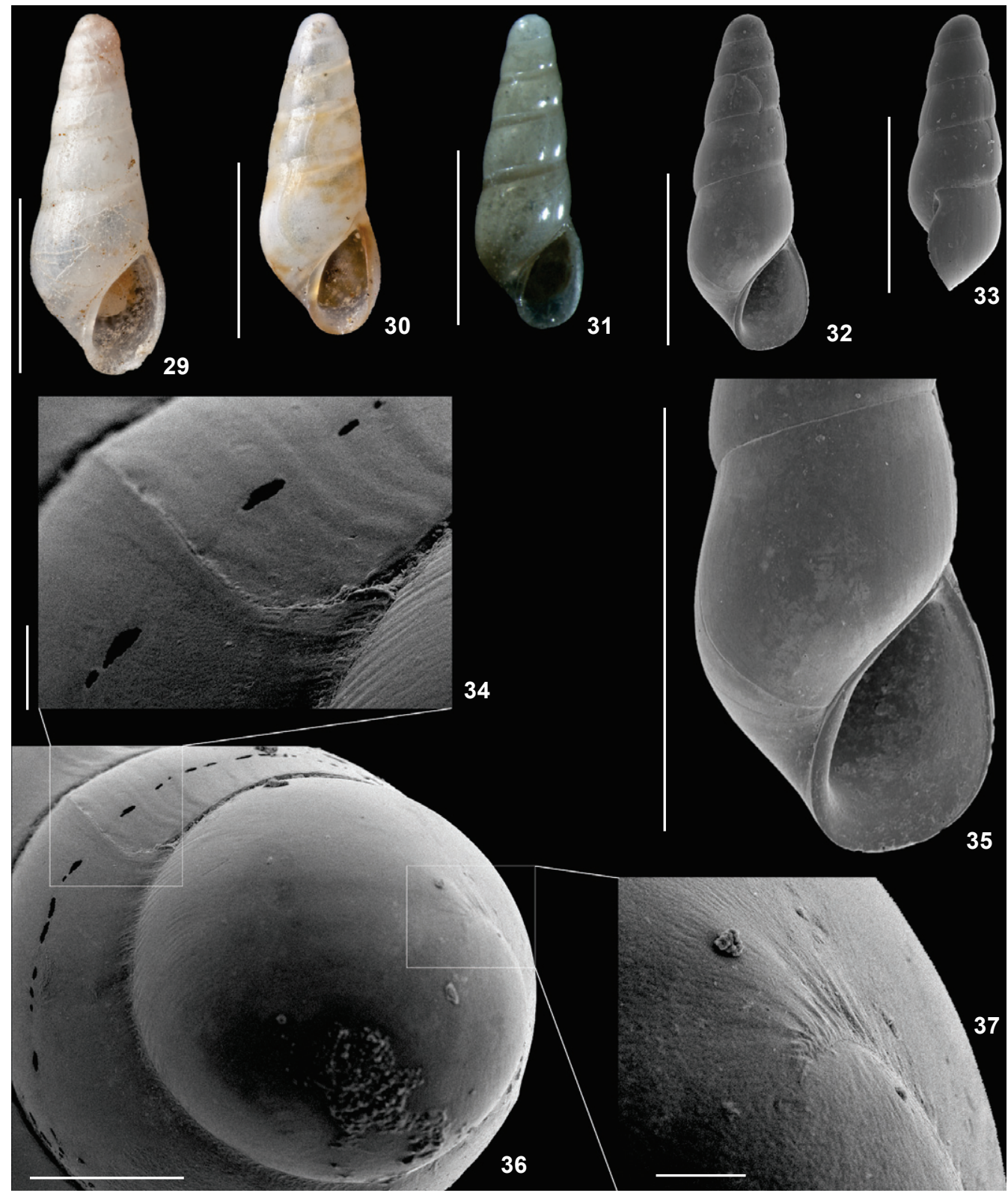

Figures. 29-37. (29-30) Fusceulima minuta, lectotype and paralectotype NHMUK 1885.11.5.2065, respectively; (31-37) Fusceulima cf. minuta: (31) MNRJ 17651; (32) MNRJ 17438; (33) MNRJ 17437; (34-36) IBUFRJ 19683; (37) MNRJ 17438. (29-33) whole shells; (34) detail of the terminal scar; (35) protoconch in apical view; (36) detail of suture at outset of protoconch; (37) last whorl. Scale bars: 29$33,37=1.0 \mathrm{~mm}, 34,36=20 \mu \mathrm{m}, 35=50 \mu \mathrm{m}$. Images (29-30) courtesy of Harry Taylor, NHMUK photographic unit.

\section{Fusceulima saturata sp. nov.}

Figs 38-45

Melanella sp. 1: Absalão \& Pimenta, 2005: 36, fig. 98.

Diagnosis. Broad shell with dark brown spiral band at subsutural zone; strong grooves at subsutural region of protoconch.
Description. Shell conical with a broad, obtuse apex, reaching $2.7 \mathrm{~mm}$ in length. Larval shell with 1.75 whorls, diameter about $220 \mu \mathrm{m}$; smooth, with short, fine striations below suture, from the nucleus to the strongly recurved terminal scar at the transition to teleoconch. Teleoconch with up to four whorls of slightly sinuous outline, with a slight convex- 


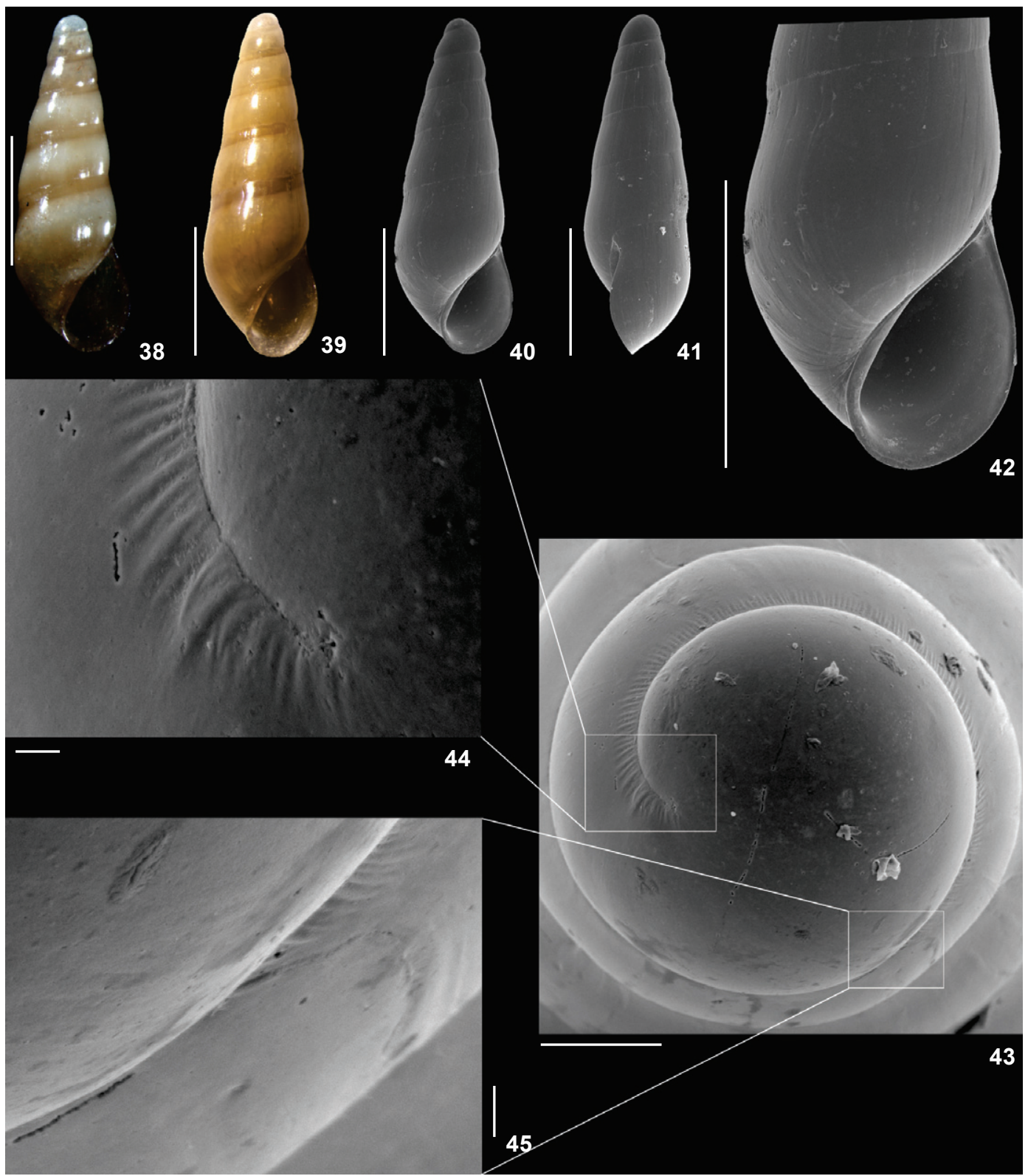

Figures 38-45. Fusceulima saturata sp. nov.: (38) holotype MNRJ 17718; (39) paratype USNM 1265881; (40, 42) paratype MNRJ 17435; (41) MNRJ 17436; (43-45) paratype MNRJ 16117; (38-41) whole shells; (42) last whorl; (43) protoconch in apical view; (44) detail of suture at the outset of protoconch; (45) detail of the terminal scar. Scale bars: $38-42=1.0 \mathrm{~mm}, 43=100 \mu \mathrm{m}, 44-45=10 \mu \mathrm{m}$.

ity on the lower region; suture shallow, rectilinear; subsutural zone distinct, occupying about 0.25 height of each whorl; surface glossy and smooth, except for very fine, almost indistinguishable growth lines; incremental scars very weak, about six with more regular intervals of 0.4-0.6 whorls. Last whorl about 0.5 total shell length; base elongated with slightly rounded outline. Aperture ovoid, pointed posteriorly with a rounded anterior margin; outer lip thin, with sinuous profile, deeply sinuate below suture, evenly curved downward, with the most projecting part in the lower half; inner lip slightly projected into parietal region; columella straight. Imperforate. Color of fresh shells brownish, with whitish or transparent apex; dark-brown spiral band at subsutural zone; beach-worn shells usually white.

Dimensions. Holotype with six whorls; length $2.6 \mathrm{~mm}$; width $0.9 \mathrm{~mm}$; height of aperture 0.8 ; width of aperture $0.5 \mathrm{~mm}$. 
Type material. Holotype MNRJ 17718: HAB 16 sta G2, 06/ vii/2009; paratypes: Campos Basin, Rio de Janeiro state: type locality: MNRJ 17435 [2 shells], MNRJ 17401 [1 shell], USNM 1265881 [ 1 shell]; HAB 16 sta F3 $\left(22^{\circ} 7^{\prime} 39.14^{\prime \prime}\right.$ S, $40^{\circ} 18^{\prime} 53.18^{\prime \prime} \mathrm{W}$, 72 m), 05/vii/2009: MNHN IM-2012-2789 [1 shell], MNRJ 17436 [ 2 shells]; HAB 11 sta G2 (2158'59.34"S, 40²5'16.31"W, 137 m), 25/ii/2009: MNRJ 16117 [3 shells]; HAB 11 sta E2 (22 ${ }^{\circ} 6^{\prime} 51.25^{\prime \prime}$, 40³9'4.44"W, 53 m), 26/ii/2009: MNRJ 16118 [1 shell]; HAB 16 sta D5 (22³1'2.68"S, 40³1'39.03"W, $137 \mathrm{~m}), 03 / \mathrm{vii} / 2009$ : MNRJ 17650 [ 2 shells]; REVIZEE Central sta D3 (22 $52^{\prime} 00^{\prime \prime} \mathrm{S}, 41^{\circ} 09^{\prime} 00^{\prime \prime} \mathrm{W}$, 80 m), 23/ii/1996: MORG 39716 [1 shell]; Cabo Frio VII sta 6165 ( $23^{\circ} 02.8^{\prime} \mathrm{S}, 42^{\circ} 46^{\prime} \mathrm{W}, 56 \mathrm{~m}$ ): MORG 38898 [ 1 shell]; Cabo Frio VII sta $6192\left(23^{\circ} 25.5^{\prime} \mathrm{S}, 44^{\circ} 00^{\prime} \mathrm{W}, 67 \mathrm{~m}\right)$ : IBUFRJ 15232 [1 shell]; Arquipélago de Santana, Macaé, 12-38 m, Astro Garoupa coll. 35/v/1993: MNRJ 33524 [5 shells], IBUFRJ 19682 [8 shells], MZSP 118421 [8 shells]; off São Paulo state: MBT sta 81, 39I (24² $46^{\prime}$ ', 455'ㄴ, 72 m), 16/vi/1970: MZSP 37081 [1 shell].

Additional material. Brazil: Rio de Janeiro: Campos Basin, (Arquipélago de Santana, Macaé, 12-38 m), supply boat Astro Garoupa coll., 3-5/v/1993, IBUFRJ 9614 [100 shells].

Type locality. Continental shelf of Campos Basin, Rio de Janeiro, southeast Brazil; (2158'59.9”S, 40²5'16.67”W, 52 m).

Geographic distribution. Brazil: Rio de Janeiro state, Campos Basin, and São Paulo state from 12-137 m depth.

Etymology. satur (Latin), an adjective meaning full, rich, with reference both to its relative abundance in Campos Basin.

Remarks. Fusceulima saturata sp. nov. (Figs 38-43) resembles Fusceulima minuta (Figs 29-30) in the general shape of the shell, but $F$. saturata is taller, more conical, while $F$. minuta has a conical to subcylindrical shell. Furthermore, F. saturata has a shallowly demarcated suture. Fusceulima saturata differs from $F$. projectilabrum and F. boscheineni (Figs 20-21) principally in the absence of an umbilicus. Fusceulima saturata differs markedly from Fusceulima ingolfiana in the strong convexity of the whorls in the latter species. In addition, the color pattern of Fusceulima saturata differs from all the other Atlantic species. The general shape and color pattern of this species is more similar to Fusceulima goodingi Warén, 1981, described from New Zealand waters (WARÉN 1981), but the shells studied by us are even taller and $F$. goodingi possesses whorls that are almost cylindrical in contrast to the slightly sinuous outline of the whorls in F. saturata.

\section{Fusceulima toffee sp. nov.}

Figs 46-53

Diagnosis. Elongated shell (about $2.9 \mathrm{~mm}$ high/0.8 mm width), with high ovoid aperture; color brownish, with whitish or transparent apex.

Description. Shell conical with a broad, obtuse apex, reaching $2.9 \mathrm{~mm}$ in length. Larval shell about 1.8 whorls, diameter about $350 \mu \mathrm{m}$; smooth, with short, fine striations below suture, from the nucleus to the strongly recurved terminal scar at the transition to teleoconch. Teleoconch with up to 3.2 whorls of sinuous outline, with a convexity on the lower region; suture more impressed, rectilinear; subsutural zone distinct, occupying about 0.15 height of each whorl; surface glossy and smooth, weak incremental scars, about six with irregular intervals of 0.3 0.9 whorls. Last whorl with about 0.6 total shell length; base elongated with slightly rounded outline. Aperture high, ovoid, acute posteriorly with a rounded anterior margin; outer lip thin, of sinuous profile, sinuate below suture, evenly curved downward, with the most projecting part at the upper half; inner lip slightly projected into parietal region; columella straight. Imperforate. Color of fresh shells brownish, with whitish or transparent apex; false suture distinguished by a dark brown color; beach-worn shells usually cream or yellowish.

Dimensions. Holotype with 5 whorls; length $2.8 \mathrm{~mm}$; width $0.8 \mathrm{~mm}$; aperture height $1.1 \mathrm{~mm}$; aperture width $0.5 \mathrm{~mm}$.

Type material. Holotype MNRJ 17400: HAB 13 sta H2, 09/iii/2009; paratypes: BRAZIL, Espírito Santo: Campos Basin, HAB 13 sta I1 ( $\left.21^{\circ} 10^{\prime} 56.54^{\prime \prime} \mathrm{S}, 40^{\circ} 28^{\prime} 33.22^{\prime \prime} \mathrm{W}, 26 \mathrm{~m}\right)$, 05/iii/2009, MNRJ 16119, [3 shells]; Rio de Janeiro: Campos Basin (213' $36^{\prime \prime}$ S, 40 36'59"W), x/2002, MNRJ 33528 [1 shell], USNM

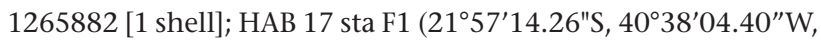
26 m), 18/vii/2009, MNRJ 17702, [1 shell].

Type locality. Continental shelf of Campos Basin, Rio de

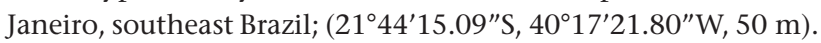

Geographic distribution. Brazil: Espírito Santo and Rio de Janeiro, Campos Basin, from 26-50 m depth.

Etymology. This species is named after its caramel color of the shell, resembling a toffee candy. Epithet as a noun in apposition.

Remarks. Fusceulima toffee sp. nov. (Figs 46-51) has a slightly sinuous whorl outline, similar to $F$. saturata sp. nov. (Figs 38-41) and F. minuta (Figs 29-30), but the elongate aperture (Fig. 50) clearly discriminates this species from the others that have a shorter aperture. In addition, the evenly curved outer lip has a different tortuosity from the common shape, not curving backward immediately below the suture, differing from all other species of Fusceulima. The color of F. toffee is more similar with the color of Fusceulima fulva (Watson, 1897), but $F$. fulva does not show the above-mentioned features of $F$. toffee.

\section{DISCUSSION}

Fusceulima and Halielloides are somewhat similar in shell morphology, especially in the dome-shaped apex and the ovoid aperture. Species of Halielloides have more-convex whorls, but Fusceulima ingolfiana Bouchet \& Warén, 1986 is an exception, with very convex whorls, resembling Halielloides Bouchet \& Warén, 1986.

According to Bouchet \& WARÉn (1986) the cylindrical outline of the shell and the presence of an umbilicus are some of the diagnostic characters of Halielloides. However, some species of Fusceulima also have these features; for example, $F$. projectilabrum has an almost cylindrical shape, and $F$. boscheineni (and also F. cf. boscheineni, as discussed above) possesses a developed umbilicus. A small fissure is also present in Fusceulima 


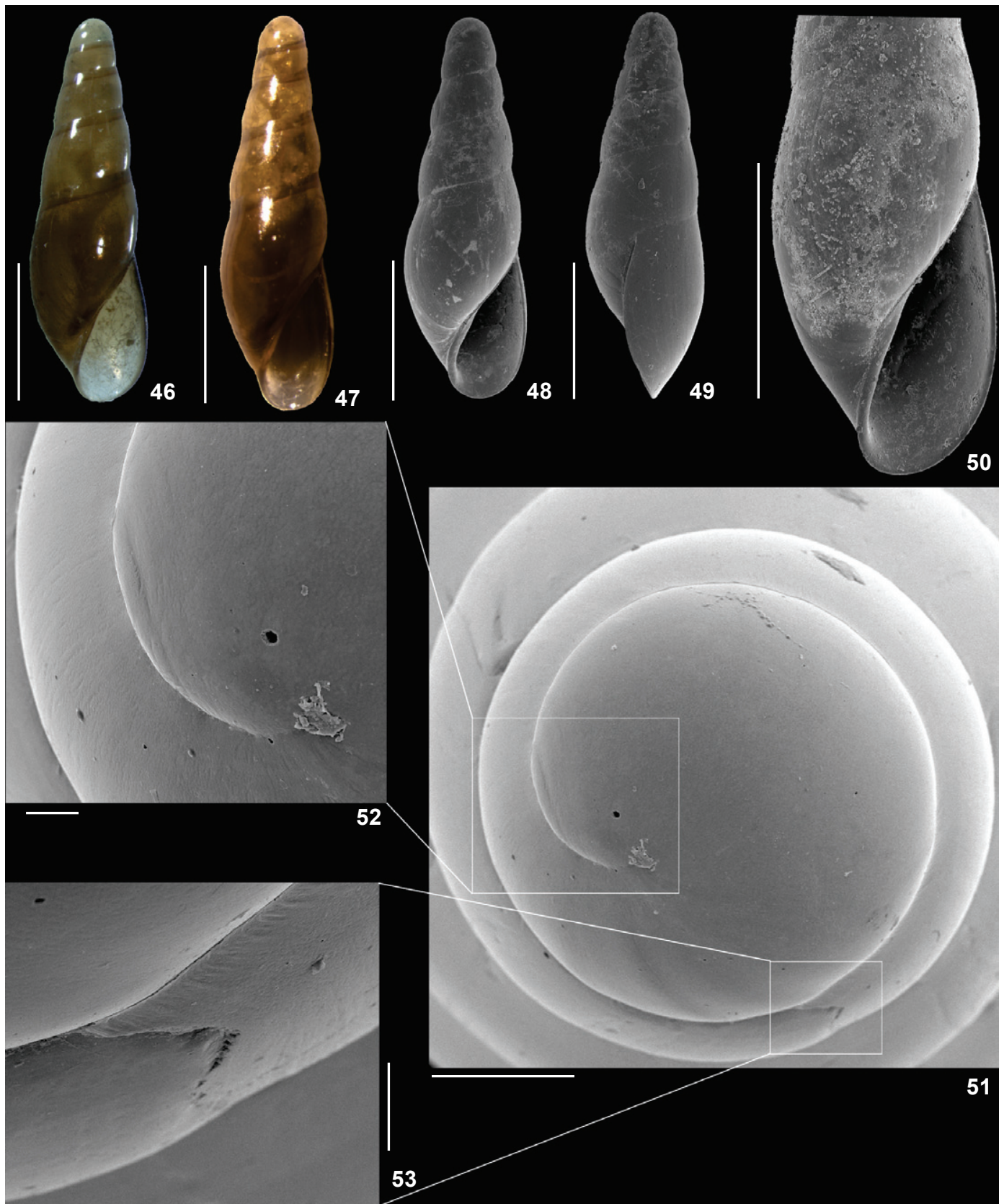

Figures 46-53. Fusceulima toffee sp. nov.: (46) holotype MNRJ 17400; (47) paratype USNM 1265882; (48-50) paratypes MNRJ 16119; (51-53) paratype MNRJ 33528; (46-49) whole shells; (50) last whorl; (51) protoconch in apical view; (52) detail of suture at the outset of protoconch; (53) terminal scar. Scale bars: $46-50=1.0 \mathrm{~mm}, 51=100 \mu \mathrm{m}, 52-53=20 \mu \mathrm{m}$.

sordida (Watson, 1897), an eastern Atlantic species, as stated by Watson (1897) in the original description, and in $F$. projectilabrum (Bouchet \& WARÉN 1986). However, in all of the above cases, such a fissure characterizes an umbilicus similar to that present in F. boscheineni.
The four species of Fusceulima treated here have small and short grooves, mainly on the subsutural region of the protoconch whorls (Figs 25-27, 34-36, 43-45, 51-53), especially visible close to the base of the protoconch and to the terminal scar, where this ornamentation stops, and is absent from the 
teleoconch whorls. This feature was not examined in the past in other eulimids and perhaps renders the classification of these species in the same genus more robust, even with different shapes and with the presence of an umbilical fissure in $F$. boscheineni. Among the species studied by us, this characteristic is especially visible in F. saturata (Figs 43-45), while in $F$. jacksonensis, the type species of the genus, some very tiny grooves can be seen (indicated by white arrows in Fig. 19), in spite of the eroded state of the shells.

Few species in other eulimid genera possess this feature (pers. obs.), and possibly this is not an exclusive feature of the genus. The possibility that the grooves are merely signs of growth of the shell in the protoconch region or are associated with the type of larval development, in this case lecitotrophy for all the species of Fusceulima studied by us, requires further investigation, but Halielloides cf. ingolfiana does not have grooves (Figs 9-10), nor do many other eulimids.

Thus, we consider that the umbilicus is a variable characteristic in Fusceulima and the short axial grooves on the protoconch are a potential diagnostic character. Their occurrence in other Fusceulima species requires further examination.

AbSAlão (2010) reported "Halielloides (?) sp." from Campos Basin, expressing uncertainty as to the generic assignment. This record was based on broken specimens dredged from $800 \mathrm{~m}$ depth (IBUFRJ 15086, IBUFRJ 17209) and cannot be evaluated here, as the shells are damaged and does not allow a reliable determination. Nevertheless, the presence of Halielloides cf. ingolfiana in the material examined in this study confirms that Halielloides occurs in the South Atlantic. Fusceulima, on the other hand, has wider geographic range, with most species recorded from the Indo-Pacific, Mediterranean and North Atlantic (Thiele 1925, LASERon 1955, BOUChet \& WarÉn 1986).

Our choice to report Halielloides cf. ingolfiana, Fusceulima cf. boscheineni and Fusceulima cf. minuta without a definitive determination (expressed by the use of "cf.") is based on the absence of evidence to support that a population from the western Atlantic continental shelf is somehow connected to those on the northeastern Atlantic continental shelf. Additionally, the lack of a clear morphological feature that could distinguish the shells from Brazil from the shells from the northeastern Atlantic belonging to the above-mentioned species led us to refrain from describing this material as new species.

Pimenta et al. $(2009,2011)$ advocated that in the absence of supporting data to justify the existence of amphi-Atlantism in species of Pyramidellidae, this possibility should be viewed with caution, avoiding the introduction of new names or proposal of wide distributional ranges without proper foundation. Pyramidellidae also includes cases of shells with identical morphology occurring in shallow localities (continental shelf) of the eastern and western Atlantic.

In the case of Eulimidae, a similar approach should be employed. There is little available knowledge about the duration of the larval phase in this family. However, the type of protoconch present in the species studied by us indicates that it is short. The species of Halielloides and Fusceulima treated here do not have more than two protoconch whorls, and the whorls are more than $200 \mu \mathrm{m}$ in diameter, suggesting lecithotrophic development (WARÉN 1984). Rectilabrum lanceolatum Bouchet \& Warén, 1986 is one of the few species with inferred planktotrophy and anatomical studies that confirm an amphi-Atlantic distribution, with records from the northeastern Atlantic and Virginia, USA (Bouchet \& WARÉn 1986, 1994, Rosenberg 2009); planktotrophy is not a predominant characteristic in deep-sea eulimids from the North Atlantic (BOUCHET \& WARÉN 1994). In addition, there is no evidence of rafting that would guarantee continuity of such distant populations. Although other intrinsic factors can affect dispersal ability (Paulay \& Meyer 2006), paucispiral protoconchs are not related to wide distributions, and thus the taxa treated here as "cf." possibly have a short planktonic period or lack of this period, which reduces their dispersal capacity.

Thus, the question of taxonomic treatment remains: such taxa are either considered conspecific under the application of the strict morphological species concept, in this case, based on the available shell morphology data, or they are deemed cryptic but distinct species when it comes to shell-morphology. An accurate taxonomic study including the morphology, biology and genetics of species provisionally identified here is necessary to elucidate the taxonomy of these specific cases, or even a possible complex of sibling species.

\section{ACKNOWLEDGMENTS}

We are grateful to M. Reid and A. Miller (AMS), D. EibyeJacobsen (ZMUC), M.G. Harasewych (USNM), R. Absalão and C. Oliveira (IBUFRJ), L.R.L. Simone and D. Cavallari (MZSP) for the loan of material. A. Salvador and H. Taylor (NHMUK) for photographs of type material. W. Engl for exchanging information and the loan of material. J. Reid for revising the English text. Three anonymous reviewers for their contribution to this manuscript. A. Veiga and B. Cordeiro for SEM operation. Petrobras S.A., for making the collection and study of material from the Habitats Project possible. FAPERJ (Fundação Carlos Chagas Filho de Amparo à Pesquisa do Estado do Rio de Janeiro), that provided financial support through project E-26/110.325/2014 and project E-26/110.068/2014. CNPq (Conselho Nacional de Desenvolvimento Científico e Tecnológico) for a scholarship to L.S. Souza.

\section{LITERATURE CITED}

Absalão, R.S. 2010. Mollusca, p. 31-95. In: H.P. LaVRado \& A.C.S. BRASIL (Eds). Biodiversidade da região oceânica profunda da Bacia de Campos: Macrofauna. Rio de Janeiro, SAG Serv., 230p.

Absalão, R.S. \& A.D. Pimenta. 2005. Moluscos marinhos da APA do Arquipélago de Santana, Macaé, RJ. Rio de Janeiro, Editora Ciência Moderna, 84p. 
Albano, P.G.; B. Sabelli \& P. Bouchet. 2011. The challenge of small and rare species in marine biodiversity surveys: microgastropod diversity in a complex tropical coastal environment. Biodiversity Conservation 20: 3223-3237. doi: 10.1007/s10531-011-0117-x

Barros, J.C.N.; I.P. PADOVAn \& F.N. SANTOS. 2001. Uma nova espécie do gênero Scalenostoma Deshayes, 1863 (Gastropoda, Eulimidae) para o Nordeste do Brasil. Tropical Oceanography 29 (2): 175-181.

Bouchet, P. 2014. Eulimidae Philippi, 1853. World Register of Marine Species, available online at: http://www.marine species.org/aphia.php? $\mathrm{p}=$ taxdetails\&id=135 [Accessed: 2014/VIII/2001]

Bouchet, P. \& A. WARÉN. 1986. Revision of the northeast Atlantic Aclididae, Eulimidae, Epitoniidae (Mollusca, Gastropoda). Bollettino Malacologico (Suppl. 2): 299-576.

Bouchet, P. \& A. Warén. 1994. Ontogenetic migration and dispersal of deep-sea gastropod larvae, p. 98-117. In: C.M. Young \& R.J. Eckelbarger (Eds). Reproduction, larval biology and recruitment of the deep-sea benthos. New York, Columbia University Press, 336p.

Bouchet, P. \& S. Gofas. 2014. Fusceulima Laseron, 1955. World Register of Marine Species, available online at: http:// www.marinespecies.org/aphia.php/aphia.php?p=taxdetails \&id=137973 [Accessed: $2014 /$ VIII.2012]

Bouchet, P.; P. Lozouet; P. Maestrati \& V. Heros. 2002. Assessing the magnitude of species richness in tropical marine environments: exceptionally high numbers of molluscs at New Caledonia site. Biological Journal of the Linnean Society 75: 421-436. doi: 10.1046/j.1095-8312.2002.00052.x

Bush, K.J. 1909. Notes on the family Pyramidellidae. American Journal of Science 27: 475-484.

Dgebuadze, P.Y.; A.E. Fedosov \& Y. Kantor. 2012. Host specificity of parasitic gastropods of the genus Annulobalcis Habe, 1965 (Mollusca, Gastropoda, Eulimidae) from crinoids in Vietnam, with descriptions of four new species. Zoosystema 34: 139-155. doi: 10.5252/z2012n1a6

ENGL, W. 1998. New species of the family Eulimidae from the Canary Islands. Part 3: Description of Fusceulima boscheineni n.sp. La Conchiglia 289: 11-14.

Espinosa, J.; J. Ortea; R. Fernández-Garcés \& L. Moro. 2007. Adiciones a la fauna de moluscos marinos de la península de Guanahacabibes (I), con la descripición de nuevas especies. Avicennia 19: 63-88.

Folin, L. 1867. Rade de Pernambouc. Les Fonds de la Mer 1: 44-48.

Jefreteys, J.G. 1884. On the Mollusca procured during the 'Lightning' and 'Porcupine' Expeditions, 1868-70. (Part VIII). Proceedings of the Zoological Society of London: 241-372.

Laseron, C.F. 1955. Revision of the New South Wales eulimoid shells. The Australian Zoologist 12: 83-107.

LEAL, J.H. 1991. Marine prosobranch gastropods from oceanic islands off Brazil: Species composition and biogeography. Oegstgeest, Universal Book Services, X+418p.

Lima, S.F.B.; J.C.N. Barros; S.V. Silva; M.C.F. Santos \& E. Cabral. 2005. Boletim Técnico-Científico do CEPENE 13 (2): 151155.

Paulay, G. \& C. Meyer. 2006. Dispersal and divergence across the greatest ocean region: do larvae matter? Integrative and Comparative Biology 46 (3): 269-281.

Peñas, A.; E. Rolán; A.A. Luque; J. Templado; D. Moreno; F. Rubio; C. Sales; A. Sierra \& S. Gofas. 2006. Moluscos marinos de la islã de Alborán. Iberus 24 (1): 23-151.

Pimenta, A.D.; R.S. Absalão \& C. Miyaji. 2009. A taxonomic review of the genera Boonea, Chrysallida, Fargoa, Mumiola, Odostomella and Trabecula (Gastropoda, Pyramidellidae, Odostomiinae) from Brazil. Zootaxa 2049: 39-66.

Pimenta, A.D.; F.N. Santos \& R.S. Absalão. 2011. Taxonomic revision of the genus Eulimella (Gastropoda, Pyramidellidae) from Brazil, with descriptions of three new species. Zootaxa 3063: 22-38.

Queiroz, V.; L.S. Souza; A.D. Pimenta \& C.M. Cunha. 2013. New host records to Melanella (Caenogastropoda: Eulimidae) from the Brazilian coast. Marine Biodiversity Records 6: 1-5. doi: 10.1017/S1755267213000407

Rios, E.C. 2009. Compendium of Brazilian Seashells. Rio Grande, Editora Evangraf, 668p.

Rosenberg, G. 2009. Malacolog 4.1.1: A Database of Western Atlantic Marine Mollusca. Version 4.1.1, avalaible online at: http://www.malacolog.org

Simone, L.R.L. 2002. Three new deepwater species of Eulimidae (Caenogastropoda) from Brazil. Novapex 3 (2-3): 55-60.

Simone, L.R.L. \& A. Birman. 2006. A new species of Eulimostraca (Mollusca, Caenogastropoda, Eulimidae) from deepwater of the southwest Brazil. Strombus 13: 15-17.

TAKANO, T. \& Y. KANO. 2014. Molecular phylogenetic investigations of the relationships of the echinoderm-parasite family Eulimidae within Hypsogastropoda (Mollusca). Molecular Phylogenetics and Evolution 79: 258-269. doi: 10.1016/ j.ympev.2014.06.021

ThiELE, J. 1925. Gastropoda der Deutschen Tiefsee-Expedition. Teil II. Deutsche Tiefsee-Expedition, 1898-1899, 17 (2): 35382. In: Wissenschaftliche Ergebnisse der Deutschen Tiefsee-Expedition auf dem Dampfer "Valdivia" 18981899. Jena, Gustav Fischer.

VERRILL, A.E. 1884. Second catalogue of Mollusca recently added to the fauna of the New England coast and the adjacent parts of the Atlantic, consisting mostly of deep-sea species, with notes on others previously recorded. Transactions of the Connecticut Academy 6 (1): 139-294.

WARÉN, A. 1981. Eulimid gastropods parasitic on echinoderms in the New Zealand region. New Zealand Journal of Zoology 8: 313-324. doi: 10.1080/03014223.1981.10430611

WARÉN, A. 1984. A generic revision of the family Eulimidae (Gastropoda, Prosobranchia). Journal of Molluscan Studies 
13 (Suppl. 13): 1-96. doi: 10.1093/mollus/49.Supplement_13.1 WARÉn, A. 1989. New and little known Mollusca from Iceland. Sarsia 74: 1-28.

WARÉn, A. 1991. New and little known Mollusca from Iceland and Scandinavia. Sarsia 76: 53-124.
Watson, R.B. 1883. Mollusca of H.M.S. 'Challenger' Expedition. Part XVII. Zoological Journal of the Linnean Society 17: 112-130. doi: 10.1111/j.1096-3642.1883.tb02043.x

Watson, R.B. 1897. Marine Mollusca of Madeira. Journal of the Linnean Society of London 26: 233-329.

Submitted: 19.VIII.2014; Accepted: 31.X.2014.

Editorial responsibility: Marcos D.S. Tavares 